\title{
Study on Generating Factors of Xi Jinping's Socialist Ideology with Chinese Characteristics in New Era
}

\author{
Chen Wenlin ${ }^{1,2}$ \\ ${ }^{1}$ South China Normal University, School of Marxism, Guangdong, Guangzhou, 510631, China \\ ${ }^{2}$ Shaoguan University, School of Marxism, Guangdong, Shaoguan, 512005, China
}

Keywords: Xi Jinping's socialist ideology with Chinese characteristics in new era; people-centered; new era; Marxism

\begin{abstract}
Chinese excellent traditional culture is the cultural source of $\mathrm{Xi}$ Jinping's socialist ideology with Chinese characteristics in new era; the situation of the world, nation and the Party is realistic foundation; Marxism is the theoretical source; and core leadership is the main cause. These four forming factors contain the connection of history and reality, subjectivity and objectivity, and theory and practice, which constitutes the historic, realistic, theoretical and subjective dimension in Xi Jinping’s socialist ideology with Chinese characteristics in new era.

$\mathrm{Xi}$ Jinping's socialist ideology with Chinese characteristics in new era is systematical and scientific ideological theory system surrounding the major issues of the times, and a new leap and the latest theoretical achievement of the localization of Marxism in China. At present, researches of Xi Jinping's socialist ideology with Chinese characteristics in new era in academic field mainly focus on connotation, content and significance, rare on its generation factors. This paper conducts exploration on forming factors of Xi Jinping's socialist ideology with Chinese characteristics in new era from historic, realistic, theoretical and subjective dimension, hopefully to provide inspirations and reference for rich connotation of Xi Jinping's socialist ideology with Chinese characteristics in new era.
\end{abstract}

\section{Chinese excellent traditional culture: the cultural source}

Xi Jinping's socialist ideology with Chinese characteristics in new era originates from Chinese excellent traditional culture, and the inheritance and deposit of Chinese excellent traditional culture. Xi Jinping pays great attention to Chinese excellent traditional culture and considers it as important cultural source of national governance. In the series of articles, speeches and interviews of Xi Jinping, the classics are cited in many contents, which forms unique "Xi's style". Xi Jinping cited, "The flourish politics depends on respecting the public opinion" from Gunzi• On Shepherding of the People to strengthen people-centered ruling for people, clearly pointed out that "serve the people wholeheartedly is the basic starting point and foothold of any of the Party's actions...All work of the Party shall takes the fundamental interests of the overwhelming majority of the people as the highest standard." He cited "The governance relies on giving peace to the people, which relies on understanding the sufferings of the people" from Answer Fujian Governor Geng Chutong to strengthen to respect and love people, and focus on people's livelihood to promote social fairness and justice and guarantee that people can live and work in peace and contentment; he cited "Consider the situation, take measures based on changes, and everything is possible" to strengthen to keep up with the times and conduct comprehensive in-depth reform, which drives us to feel the politic wisdom and times connotation of Chinese excellent traditional culture.

People-centered idea in Xi Jinping's socialist ideology with Chinese characteristics in new era is the embodiment in times of people-oriented ideology in Chinese excellent traditional culture, which is rich in connotation, containing the politic wisdom and governance strategy of people-oriented idea. "People-centered" idea is the soul of Xi Jinping's socialist ideology with Chinese characteristics in new era. "People" and "heart" are key words throughout the idea, manifesting the 
times connotation of people-oriented ideology in Chines excellent traditional culture. In the report of the 19th National Congress of the CPC, the "people" appeared a total of 203 times, and there were 57 "hearts". The frequency is high, inspiring the people and stimulating resonance. Whether "stay true to the mission", "the sense of gain, well-being, and security" or "to always breathe with the people, share the fate, and connect with the heart", not only shows the original intention of "where we come from", also contains the fundamental purpose of the CPC to serve the people wholeheartedly. It not only solves the fundamental problems of why and who enjoys it, but also demonstrates the ruling idea of governing for the people, not only following the Marxism historical materialism, but also indicating power and direction of China's development.

\section{The situation of the world, nation and the Party: realistic foundation}

The situation of the world, nation and the Party is the times background and realistic foundation of Xi Jinping's socialist ideology with Chinese characteristics in new era, which is the theoretical crystallization of "responsing to deep changes in the situation of the world, nation and the Party" [2].

In the situation of the world, the world is in stage of adjustment with great development and transformation. World multi-polarization, economic globalization, and cultural diversity have developed in depth, and instability and uncertainty such as terrorism, climate change, and regional conflicts are particularly prominent. In the face of the world change, Xi Jinping made a scientific judgment as early as 2014, "The world today is a world of change, a new opportunity, and a new challenge, a world with deep adjustment of international systems and international order, a world where international power contrasts profoundly change towards a world that is conducive to peace and development." ${ }^{3]} \mathrm{Xi}$ Jinping can understand the overall situation strategically and profoundly explain the changes and invariable factors in the international situation. He not only emphasizes the complexity of the development and evolution of the international pattern, but also clarifies the long-term nature of the international order dispute; he not only emphasizes the twists and turns of the adjustment of the world economy, but also explains the uncertainty of the surrounding environment; he also clarifies that the multi-polarization situation of the world will not change, but also clarifies that the process of economic globalization will not change. On the basis of accurately grasping the world situation, and Xi Jinping's socialist ideology with Chinese characteristics in new era, a series of new ideas, new strategies, new ideas have been formed to promote the construction of new international relations, advocate the implementation of the "Belt and Road" Initiative, and promote the building of a community of shared future for mankind, and create a comprehensive diplomatic layout; in the situation of the nation, during the 40 years of reform and opening-up, especially since the 18th National Congress of the CPC, China has made tremendous historical achievements. The GDP ranks second in the world, the people's life is constantly improving, and the ecological civilization construction has achieved remarkable results... Socialism with Chinese characteristics has entered a new era, which is the era judgment of Xi Jinping's socialist ideology with Chinese characteristics in new era for Chinese historic position. "Xi Jinping's socialist ideology with Chinese characteristics in new era and the new era of socialism with Chinese characteristics are two propositions with rich internal relations." ${ }^{44]} \mathrm{Xi}$ Jinping's socialist ideology with Chinese characteristics in new era, whether the "five in one" general layout, the "Four-Pronged Comprehensive Strategy”, "five principles of development”, or “take out tigers”, "swat flies”, "hunt down foxes", "three stricts and three honests", "Two Studies, One Action", is an inevitable requirement of the new era, a practical measures for building a well-off society in an all-round way and realizing the great rejuvenation of the Chinese nation, and the realistic foundation for the formation of Xi Jinping's socialist ideology with Chinese characteristics in new era; in the situation of the Party, The most essential feature of socialism with Chinese characteristics is the leadership of the Communist Party of China. "The Four-Way Test" facing by the CPC are long-term and complicated, "The Four-Way Danger" facing by the CPC are sharp and severe, and the ruling environment, and factors influencing the Party's advanced nature, and weakening the Party's purity are also complex and changeable. When in Standing Committee of the Political Bureau of the 19th CPC Central Committee meeting with Chinese and foreign press, Xi Jinping stressed, "The 
Communist Party of China is the largest party in the world, and it should behave like the largest Party." [5] As the ruling party, "It takes a good blacksmith to make steel" ${ }^{[6]}$; As a great project of Party building, Xi Jinping put forward "to strengthen the construction of Party's long-term governance capacity, advanced nature and purity as the main line, take the Party's political construction as the guide, and comprehensively promote the Party's political, ideological, organizational, work style, and discipline construction, and integrate system construction throughout it..." ${ }^{[7]}$ The general requirements for Party building in new era have pointed out the correct direction and provided basic reference for the great project of Party building in new era.

\section{Marxism: the theoretical source}

Xi Jinping's socialist ideology with Chinese characteristics in new era is guided by Marxism and follows the basic principles, positions, viewpoints and methods of Marxism, which is integrated throughout it and is the theoretical source and intrinsic foundation for it.

To consolidate the foundation and conduct radical reform: learn Marxism. "Only by strengthening learning can we enhance the scientific, predictive and proactive nature of work, and can leadership and decision-making reflect the times, grasp the regularity, and be creative." ${ }^{[8]}$ Only learning can we really understand the truth, believe and practice it. On one hand, the core content of learning is the belief in Marxism and the belief in socialism and communism. "Strengthening the ideals and beliefs and sticking to the spiritual pursuit is always the foundation for the Communists to live and work in peace." [9] Therefore, it is necessary to take firmly ideals and beliefs as the primary task of the Party's ideological construction, arm the mind with Marxist scientific theory, improve Party spirit, strengthen the education of ideals and beliefs, and consolidate the spirit and the mind to become stronger; on the other hand, the principle and requirement of learning is that it shall be "systematical rather than piecemeal, practical rather than hollow" ${ }^{[10]}$. Xi Jinping emphasized, "To master the basic theory of Marxism as special skill, and to learn Marxism-Leninism honestly and sincerely..." ${ }^{111]}$, in this way, we can achieve true learning, true understanding, true belief, and true practice.

To strengthen the foundation: stick to people-centered idea. Xi Jinping's socialist ideology with Chinese characteristics in new era shall be people-centered, embodies the value orientation of the people is supreme, and creates the people's dominant position. For people-centered idea, it is necessary to regard the realization of people's happiness as the purpose and destination of development, and take increasing people's well-being and promoting the all-round development of people as the starting point and the foothold of development, so as to realize the development for the people, development by the people, and development achievements shared by the people. In Xi Jinping's socialist ideology with Chinese characteristics in new era, whether the main contradictions of the society in the new era or the people-centered orientation, is to meet the growing material and cultural needs of the people; whether the ecological civilization construction, social governance or comprehensive strengthening of Party discipline, shall seize the most concerned, most direct, and most realistic interests of the people; whether the "Four-Pronged Comprehensive Strategy" or "five principles of development", is finally to allow the people to have more sense of gain, well-being and safety.

To be realistic und pragmatic: follow the world outlook and methodology of Marxism. "Marx's entire world outlook is not a doctrine, but a method. It does not provide a ready-made dogma, but a starting point for further research and a method for such research." ${ }^{[12]}$ This method not only indicates the practice orientation of Marxism, also highlights the need for the combination of theory and practice. As Deng Xiaoping emphasized, "We firmly believe in Marxism, but Marxism must be combined with China's reality. Only Marxism combined with China's reality is the Marxism we need." ${ }^{[13]}$ Xi Jinping's socialist ideology with Chinese characteristics in new era follows the Marxist world outlook and methodology. For instance, in the historical orientation, it follows the principle of material unity of the world, insists on being realistic, and makes an accurate judgment of socialism with Chinese characteristics in the new era; in the main contradictions of society, it follows the basic principles of the contradictory movement of things of Marxism, persists in 
dialectical unification relations between cognition and practice, and scientifically points out that the principal contradiction of society has been transformed into contradictions between the people's growing needs for a better life and the inadequate and imbalanced development. This principal contradiction "is not coming out of thin air, not subjective delusion, but the result of in-depth understanding of China's economic and social development practices, and a scientific summary of reform and opening-up practices." ${ }^{[14]}$ In terms of reform, it proceeds from the whole situation and puts forward a major strategic plan for "comprehensively deepening reform" that affects the overall development of the Party and the nation, and follows the basic principles and methods of Marxism, such as entirety and part, and overall consideration; In strengthening the Party discipline, it points out the objective reality of "The Four-Way Danger" and "The Four-Way Test", which not only points out that there must be problem awareness and overall situation in the face of contradictions, but also clarifies the strategic, innovative and dialectical thinking that resolves contradictions, also proposes that the countermeasures to resolve contradictions are to enhance the learning ability, the ability to reform and innovate, the ability of scientific development, the ability of work for the masses, and the skills of implementation; In ecological civilization construction, it adheres to the development concept of "innovation, coordination, green, openness, sharing” and the principle of "giving priority to conserving resources, protecting the environment, and letting nature restore itself”, promotes green development and proposes the goal of "making our skies blue again to build a beautiful China", which not only follows the Marxist principle of material unity, but also highlights the dialectical unity of Marxist material and consciousness....

\section{The core leadership: the main cause}

"An action matters than a series of guidelines." Learning by doing. Practice is the source of theory. Xi Jinping's socialist ideology with Chinese characteristics in new era, originates from the construction practice of socialism with Chinese characteristics in new era and Xi Jinping's ideological cognition and practice. Xi Jinping's rich experience and grassroots practice are not only the evolution stage of ideological understanding, but also the tempering process of ability and quality. It is not only the formation of personality cultivation, but also the accumulation of personal practical experience. It is not only an important component of the core competence of the leader, but also an indispensable main elements of the formation of Xi Jinping's socialist ideology with Chinese characteristics in new era.

Family tradition cultivates the personality quality. Xi Jinping was born in a revolutionary family and was influenced by a strict family tradition. Xi Jinping said, "The noble qualities are mainly inherited and absorbed from father, from doing things to the pursuit of faith, from the innocent feelings to being diligent and thrifty in running the household, from honesty and integrity to seeking truth from facts." ${ }^{[16]}$, which is infiltrated and deeply imprinted in Xi Jinping's political thoughts. Xi Jinping emphasized, "Strengthening the construction of work style should return to the truth, and consolidate the foundation... The leading cadres should put the construction of the family tradition in an important position, being honest and whitehanded in self-cultivation and family harmony."[17] In the "Guidelines for the Integrity and Self-discipline of the Communist Party of China", it is the first time to list being honest and whitehanded in family harmony as important contents of the integrity and self-discipline of Party members and leading cadres in the form of Party disciplines and regulations, and take establishment of a good family tradition as a compulsory course for Party members and leading cadres, which highlights the institutional height of family tradition construction.

The period of educated youth cultivates the feelings of working for the people. Sincere emotions are not born or accidental, and are not cultivated overnight, but gradually condensed in long-term practice. Xi Jinping went to live and work in a production team in rural areas of northern Shaanxi. From the diet of coarse grain sauerkraut to the accommodation of cave dwellings, from flea problem to labor, from high-ranking children to Party applications rejected repeatedly, he experienced hardships that ordinary people could not imagine. Although this period of educated youth is very difficult, it has nurtured Xi Jinping's deep feelings for the people, established the ideal 
goal and the pursuit of life value, and benefited him for life. As Xi Jinping recalls, "When I came to the Yellow Land when I was 15 years old, I was confused. When I left the Yellow Land at the age of 22, I already had a firm goal in life and I was full of self-confidence. As a public servant of the people, the Northern Plateau is my root. Because this place cultivated my unchanging belief, namely to do practical things for the people!"[18], which also let him deeply understand that the people are the creators of history: "Only by obeying the people, winning the people's hearts, and making profits for the people, can we get the support from the people, and can we remain invincible." The deep feelings for the people and firm beliefs for the people cultivated by Xi Jinping in this period of educated youth have become "the historical starting point of Xi Jinping's political thoughts and the beginning of the practice of national governance" ${ }^{[20]}$, which has laid a solid foundation for adhering to the mass line, sticking to people-centered concept and practicing the Party's aim, and is the basic strategy throughout Xi Jinping's socialist ideology with Chinese characteristics in new era.

Work experience cultivates the capacity of leader. Xi Jinping's work experience is extensive, rich, deep and solid, covering almost all administrative levels, including county, city, province, and central government, spanning the central and western regions of China, the remote rural areas, to the prosperous cities, and the developed areas, involving village officials, governors, secretaries, secretary of leader of the Central Military Commission, and other positions in the Party, government and military field. This kind of rich work experience has created the capacity and style of leadership, which is not a one-step process, but the down-to-earth practice and the self-sublimation of unremitting learning. The core competence is to hold the foundation of governance, practice the way of governance, and cultivate the virtue of governance. First of all, keep the foundation of governance in mind, and stick to ideals and beliefs. Seven years of educated youth have nurtured Xi Jinping's profound sentiments for the people and established firm ideal goals and value pursuit. Xi Jinping has written ten applications for joining the Party and submitted them to the organization for more than ten times. After repeated refusals, he did not give up. It is both a result of revolutionary family education and firm loyalty to the Party. "Revolutionary ideals are the noblest" is a true manifestation of Xi Jinping's persistent pursuit of faith, to dare to eliminate all difficulties, be good at implementing new policy; dare to face the reality, strictly manage the Party's governance; dare to look at the world and be brave in the mission, "letting the people feel the infinite power of political conviction and political beliefs, and setting up a bright banner with faith and politics in the hearts of the Party and the people." ${ }^{[21]}$ Secondly, the way of governance focuses on the people. Xi Jinping's experience at the grassroots level has cultivated his deep feelings for the people, established a firm belief in doing things for the masses, and conserved the feelings for the mass that has been ruined throughout his life. "No matter in the past, present and future, it is necessary to do everything for the masses, rely on the masses, come from the masses, and go to the masses, turn the Party's correct ideas into the conscious actions of the masses, and implement the mass line to all activities of national governance." [22] The people-centered way of governance is the ideological source of people-centered idea throughout Xi Jinping's socialist ideology with Chinese characteristics in new era, and the solid foundation for Xi Jinping to stick to and practice the mass line and govern for the people; finally, the virtue of governance focuses on truth, and be an honest man. Being realistic and pragmatic in mind, that is, "sticking to people-centered in mind". We shall be willing to sacrifice and be loyal to service. It is both the result of historical materialism and the requirements of source of legality, and also the necessity for the foundation of governance; Being modest in life, that is, "diligent." We shall be diligent in practical work and actions. "To be both 'honest' and 'diligent' in governance.... To do practical things for the masses, to be solid and persistent for a long time."[23] To be pragmatic in work style, that is, "honest", which is the foundation of being officials, the way of governance and the basis of self-cultivation. We shall persuade and win people by virtue. Marsh gas program, the poverty alleviation program in eastern Fujian of "constant dropping wears the stone and A slow sparrow should make an early start", "take out tigers", "swat flies", "hunt down foxes", and so on are authentic manifestation of the Xi Jinping's cultivation of virtue of governance. 


\section{Acknowledgement}

This paper is the result of scientific research project of Shaoguan University "Research on Strengthening and Standardizing Political Life within the Party of Party Organizations in Colleges and Universities" in 2017(SY2017SK08).

\section{References}

[1] [11] Xi Jinping. Xi Jinping: The Governance of China (Volume 1) [M]. Bejing: Foreign Languages Press, 2014: 28, 154.

[2] Chen Shuguang. New Thought is Theoretical Crystallization of In-depth Changes of the Situation of the World, Nation and Party [N]. Hubei Daily, 2017-11-29 (14).

[3] Xi Jinping. The Governance of China (Volume 2) [M]. Bejing: Foreign Languages Press, 2017: 442, 165.

[4] Chen Jinlong. New Judgment of Historical Position of China’s Development [N]. Nanfang Daily, 2017-10-30 (2).

[5] Xi Jinping. New Look and New Act in New Era, Chinese People Will Live Better and Better [N]. People’s Daily, 2017-10-26 (1).

[6] [7] Xi Jinping. To win the Comprehensive Construction of Moderately Prosperous Society and Great Victory of Socialism with Chinese Characteristics in New Era- The Report of $19^{\text {th }}$ National Congress of the CPC [M]. Beijing: People's Publishing House, 2017: 61, 62.

[8] Publicity Department of the Communist Party of China. Series of Important Speeches of Xi Jinping [M]. Beijing: Xuexi Pressing House, People's Publishing House, 2016: 294.

[9] Editorial Department of People’s Daily. Xi Jinping Allusion [M]. Beijing: People's Publishing House, 2015: 227.

[10] Selected Works of Mao Zedong (Volume 2) [M]. Beijing: People's Publishing House, 1991: 533-534.

[12] Selections of Marx and Engels (Volume 10) [M]. Beijing: People's Publishing House, 2009: 691.

[13] Selections of Deng Xiaoping (Volume 3) [M]. Beijing: People's Publishing House, 1993: 213.

[14] Liu Zhuohong. New Expression of Principal Contradictions is the Correct Judgment of Great Practice in New Era [N]. Nanfang Daily, 2017-12-11 (2).

[15] Selections of Marx and Engels (Volume 3) [M]. Beijing: People's Publishing House, 2012: 355.

[16] The editing group of Xi Zhongxun's revolutionary career. Xi Zhongxun Revolutionary Career [M]. Beijing: Party History Publishing House of Communist Party of China, China Literature and History Press, 2005: 688-689.

[17] Xi Jinping. I Am the Son of the Loess Land [J]. National Catalogue of New Books, 2002(12): 26.

[18] Xi Jinping. New Talk on Zhijiang [M]. Hangzhou: Zhejiang People's Publishing House, 2007: 216.

[19] The Editing Office of Interview Records of Party School of the CPC Central Committee. Xi Jinping's Seven Years of Educated Youth [M]. Beijing: Party School of the Central Committee of CPC Press, 2017: 401.

[20] Zhou Xinmin. Core Competence: To Understand Three Years of Governance [M]. Beijing: Party School of the Central Committee of CPC Press, 2016: 152-153. 
[21] Selections of Important Materials since the 18th CPC National Congress [M]. Beijing: Central Party Literature Press, 2014: 697.

[22] Xi Jinping. Poverty Alleviation [M]. Fuzhou: Fujian People’s Pressing House, 1992: 18. 